\title{
Gazneliler ile Selçuklular Döneminde Taberistan Bölgesi ve Ziyâriler
}

\section{Esin Küçükbekir*}

\section{Özet}

Günümüzde İran topraklarının kuzey kısmında yer alan ve Mazenderan olarak adlandırılan Taberistan bölgesi tarih boyunca birçok hanedan tarafından idare edilmiştir. Selçukluların 11. yüzyılda Horasan bölgesine gelip Gaznelilerin hâkimiyet sahalarını ele geçirmeden önce, Taberistan Gazneliler tarafından yönetiliyordu. Selçuklular İran coğrafyasına hâkim olmaya başladıktan kısa bir süre sonra Taberistan Bölgesine gelmişler ve mahalli hanedan olan Ziyâriler üzerine hâkimiyet kurmuşlardır. 11. yüzyılın sonlarına kadar Selçukluların hâkimiyeti altında kalan Ziyâriler, Hasan Sabbah'a bağlı İsmailîler tarafından ortadan kaldııımıştır. Araştırmada, Taberistan bölgesinde Gazneli-Selçuklu hâkimiyeti ve bu hâkimiyet süresi içinde Ziyâriler ile olan siyasi ilişkiler incelenmiştir.

Anahtar Kelimeler: Taberistan, Gazneliler, Selçuklu Devleti, Ziyâriler.

\section{Tabaristan Region and Ziyârid Dynasty in the Period of Ghaznavids and Seljuks}

\section{Abstract}

At the present time, the Tabaristan region, which is located in the northern part of the Iranian territory and is called Mazendan, was ruled by many dynasties throughout history. Before the Seljuks came to the Horasan region in the 11th century and seized the dominance regions of the Ghaznavids, Tabaristan was being ruled by Ghaznavids. Shortly after the Seljuks began to dominate Iranian geography, they came to the Tabaristan region and established dominion over the local dynasties Ziyârids. The Ziyârids, which was under the rule of the Seljuks until the end of the 11th century, was destroyed by the İsmailîs of Hasan Sabbah. In the research has been investigated the Ghaznavid-Seljuk domination in the region and the political relations with Ziyârids.

Keywords: Tabaristan, Ghaznavids, Seljuks State, Ziyârids.

\footnotetext{
* Doktora Öğrencisi, On Dokuz Mayıs Üniversitesi, Sosyal Bilimler Enstitüsü, Tarih Anabilim Dalı, Samsun, esin.kbekir@gmail.com. (Makale gönderim tarihi: 21.02.2017, makale kabul tarihi: 18.03.2017)
}

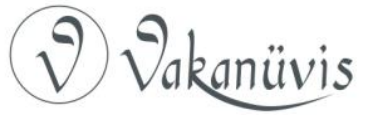




\section{Giriş}

Hudud'ul Âlem'de, bölge şöyle tarif edilmektedir: "Deylemlilerin ülkesinin büyük bir bölümünü kapsar. Hududu Çalus'dan Tamişa'ya kadar uzanır. Sayısız zengin tüccarlar sayesinde refah düzeyi yüksek bir bölgedir. Yiyecekleri daha çok pirinç unundan yapılmış ekmek ve balıktır. Evlerinin çatıları yazın ve kışın bölgenin sık sık yağış almasından dolayı kırmızı kiremitle kaplanmıştır." ${ }^{1}$ Arap coğrafyacılar tarafından Taberistan olarak adlandırılan bölgede, Hazar Denizi'nin güney kıyıları boyunca uzanan yüksek dağ sıraları bulunmaktadır. ${ }^{2}$ Bölge yüksek kesif ormanlara sahip olması ve halkının odunculuk ile ilgilenmesi sebebiyle baltalar ülkesi olarak tarif edilmiştir. ${ }^{3}$ ibn Havkal'ın Mesalik-i Memalik (Suretü'l-Arz) adlı eserinde Taberistan, düzlük bir arazi olarak belirtilmiş, halkının Arapça ve Farsçadan farklı bir diyalekte sahip olduğunu, Deylem ülkesinin birçok bölümünde bunun anlaşılmadığını ifade etmiştir. Ayrıca Taberistan ve Deylemistan'da yaşayanların çoğunun Müslüman olduğunu fakat bazılarının hala putperestlik ayinlerini uygulamaya devam ettiklerinin söylendiğini eserinde dile getirmiştir. ${ }^{4}$ İstahrî ise bölgenin çok önemli bir ipek üretim merkezi olduğunu ve üretilen ipeklerin civardaki memleketlere ihraç edildiğini, orman bakımından zengin olması münasebetiyle ağaçtan üretilen ev ve süs eşyalarının da aynı şekilde komşu memleketlere ihraç edildiğini eserinde belirtmiştir. ${ }^{5}$

Antik çağlarda Taberistan, doğal güçleri ve yaşamın gerekliliklerinden dolayı diğer ülkelerden bağımsı olması, daima kralların ve soyluların sığınma yeri ve kalesi idi. Bölgenin tek

\footnotetext{
${ }^{1}$ Vladimir, Minorsky, Hudud al-Alam, The Region of the World, Edit: C.E. Bosworth, London, 1970, s. 134.

${ }^{2}$ Guy Le, Strange, The Lands of The Eastern Caliphate, Mesopotamia, Persia and Central Asia From The Moslem Conquest to The time of Timur, Cambridge University Press, Cambridge, 1905, p.369.

3 ibnü'l Fakîh, Ebubekir Ahmed b. Muhammed el-Hemedanî, Muhtasar Kitâbü'I-Büldan, Edit: M.J.De Geoje, Leiden, 1885, s.312.

4 ibn Havkal, Mesalik ve'l Memalik, The Oriental Geography, translated: William Ouseley, Oriental Press, London 1800, s.174.

5 İstahrî, Ebu İshak Muhammed b. el-Farisi, Kitabü'l Mesâlik ve'l-Memâlik, Leiden, 1992, s.212.
}

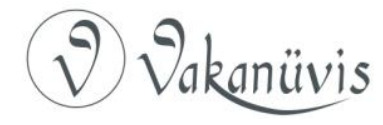


dezavantajı nemli bir iklime sahip olması ve denize yakınlığından dolayı aşırı yağış almasıydı. ${ }^{6}$

İslamiyet'ten önce Taberistan bölgesi çeşitli hanedanlar tarafından yönetilmiştir. Bölge, Müslümanlar tarafından fethedilmesine rağmen Hazar Denizi'nin güney sahillerine tam anlamıyla hâkimiyet sağlanamamıştır. Coğrafi yapı bakımından oldukça engebeli olan bölge, Elbruz sıradağlarıyla çevrili olması burayı korunaklı hale getirdiği için hanedanların uzun müddet ayakta kalmalarını sağlamıştır. ${ }^{7}$

Bölgeyi idare eden siyasi teşekküllere baktığımızda Sâsâniler döneminde "ispehbed" unvanlı valiler tarafından idare edildiğini görmekteyiz. İslam fetihlerinin zor ilerlediği bir bölge olmasına rağmen Taberistan'ın Amûl şehri Kufe valisi tarafından fethedilmiştir. Daha sonra bölge idaresi Tahirilere geçmiştir. Coğrafi konumu sebebiyle birçok toplumun sığınağı olmaya devam eden bölge, IX. yüzyılın ortalarında Tahiri yönetimine karşı isyan eden Deylemlilerin daveti üzerine Rey'den Taberistan'a gelen Hasan b. Zeyd'in hâkimiyetine geçmiş ve o da burada Taberistan Zeydileri devletini kurmuştur. Zeydi devletinin sona ermesiyle bölge yönetimi Sâmânîlerin eline geçmiş, bir müddet Zeydiler ve Sâmânîler arasında el değiştiren bölge, X. yüzyılın başlarında Ziyâriler'in hâkimiyetine girmiştir. ${ }^{8}$

\section{Ziyâriler Hanedanı ve Selçuklulara Kadar Gaznelilerin Taberistan Hâkimiyeti}

Ziyâri hanedan adını, kurucusu Merdâviç b. Ziyâr'ın babası Ziyâr b. Verdânşâh'tan alır. Soylarının Sâsâni hükümdarı Hüsrev zamanında Gilân kralı olan Arguş Ferhadan'dan geldiğini iddia ederler. ${ }^{9}$ Genel

${ }^{6}$ ibn İsfendiyar, Tarih-i Taberistan: An Abridged Translation of History of Tabaristan, translated: Edward Browne, Volume: II, Printed by: E.J. Brill, Leiden, 1905, s.30

${ }^{7}$ Hasan Yaşaroğlu, Taberistan Zeydileri, Basılmamış Doktora Tezi, Marmara Üniversitesi, Sosyal Bilimler Enstitüsü, İstanbul, 1998, s.20.

${ }^{8}$ Osman Gazi Özgüdenli, "Taberistan", İslam Ansiklopedisi, C.XXXIX, Türkiye Diyanet Vakfı Yayınları, İstanbul, 2010, s.322.

${ }^{9}$ Keykâvus b. İskender, Kabusnâme, Farsça'dan Çev. Illyasoğlu Mercimek Ahmed, Hazırlayan ve Sadeleştiren: Atilla Özkırımlı, C.ı, Kervan Yayınları, İstanbul s.77; W. Madelung, "The Minor Dynasties of Northern Iran", The Cambridge History of Iran, Edit by R.N. Frye, Vol. IV, Cambridge University

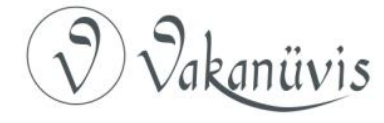


anlamda İran'da hüküm sürmüş olan hanedanların hemen hemen birçoğunun soylarını Sâsânilere dayandırdığını görmekteyiz. Bu durumu XI. yüzyıl İranı́nın dâhili bölünmüşlüğü ve siyasi iktidarsızığına rağmen eski İran kültürünü himaye etme ve yeniden canlandırma çabası içinde olmaları şeklinde yorumlayabiliriz.

Ziyâriler'in ilk hükümdarı Merdâviç, Sâmânîler'in Gilânlı ünlü kumandanı Esfâr b. Şireveyh'in hizmetine girerek onun komutanlığında önemli başarılar kazanmıştır. Esfâr'ın ele geçirdiği bölgelerde halka zulmetmesi ve halkın buna tepki göstermesinden yararlanan Merdâviç, bağımsızığını ilan etmiştir. ${ }^{10}$ Esfâr'ı öldürdükten sonra onun hâkimiyeti altındaki memleketlere yerleşmiş̧ir. Bu süreç içerisinde Taberistan'da hüküm sürmüş olan Zeydiler'in ünlü komutanı Mâkân b. Kâki ile ittifak halinde olan Merdâviç, Mâkân'ın elinde bulunan Taberistan'a yönelmek istemiştir. Aralarında vuku bulan mücadelede Merdâviç üstün gelerek Taberistan'ı ele geçirmiştir. ${ }^{11}$ Hâkimiyeti altında bulunan el-Cibâl ve çevresinde yaşayan Türklere karşı olumsuz tutumundan dolayı onların düşmanlığını kazanan Merdâviç bir müddet sonra bu Türk grupları tarafından öldürülmüştür. ${ }^{12}$ Ölümünden sonra Ziyâri hanedanın başına Veşmgir b. Ziyâr geçmiştir. Merdâviç'in adamları ve askerleri Veşmgir'e itaatlerini bildirmişler bunun üzerine Veşmgir Rey'de hüküm sürmeye başlamıştır. ${ }^{13}$

Press, Cambridge, 2008, s.212; Erdoğan Merçil, "Ziyâriler", islam Ansiklopedisi, C.XLIV, Türkiye Diyanet Vakfı Yayınları, İstanbul, 2013, s.498.

10 Madelung, "The Minor Dynasties of Northern Iran", s.212; Merçil, "Ziyâriler", s.498.

11 İbnü'l-Esir, el-Kâmil fi't-Tarih, Çev: Abdülkerim Özaydın, C.VIII, Bahar Yayınları, İstanbul, 1989, s.164.

12 İbn İsfendiyar, Tarih-i Taberistan: An Abridged Translation of History of Tabaristan, s. 217; İbnü'l-Esîr, el-Kâmil fi't-Tarih, C.VIII, s.248; Madelung, "The Minor Dynasties of Northern Iran", s.213; Filiz Akçay, Zeynü'l-Ahbâr (Tâhiriler, Saffâriler, Sâmâniler ve Gazneliler ile ilgili Kısımlar), Basılmamış Yüksek Lisans Tezi, Ordu Üniversitesi, Sosyal Bilimler Enstitüsü, Ordu, 2015, s. 498; Ahmet Güner, "Merdâvic b. Ziyâr", İslam Ansiklopedisi, C.XXIX, Türkiye Diyanet Vakfı Yayınları, İstanbul, 2004, s. 179.

13 İbn İsfendiyar, Tarih-i Taberistan: An Abridged Translation of History of Tabaristan, 217; İbnü'l-Esîr, el-Kâmil fi't-Tarih, C.VIII, s.253.

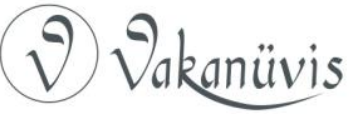


Veşmgir'in Doğu Hazar sahasında stratejik bir bölgeye sahip olması, müteakip on yıl içerisinde Ziyâriler'i, Kuzey İran'ın kontrolünü sağlama konusunda komşuları olan Sâmânîler ve Büveyhîlerle karşı karşıya getirmiştir. Veşmgir'den sonra yerine oğlu Bisutun gelmiş ve ondan sonra 978'de bu hanedanın en iyi bilinen yöneticisi Kâbus b. Veşmgir başa geçmiştir. Kâbus zalim bir diktatör olmasıyla ünlenmiştir. Ancak o aynı zamanda ünlü bir bilgin şair ve hattat idi, astroloji ve sanata hâkimdi. Büveyhîler Kâbus'un topraklarını işgal ettiği zaman Nişabur'daki on yedi yıl sürgün hayatı süresince Sâmânîlerin saray kültürüne iyice aşina oldu. İktidara döndükten sonra, Cürcân'daki zamanının önemli ilim adamlarına ve sanatçılarına destek sağladı. Sünni idi ve yönettiği bölgelerdeki Şii hareketlerine şiddetli bir şekilde kısıtlama getirdi. ${ }^{14}$

Döneminin ünlü yöneticileri arasında olduğu bilgisine devrin tarihçisi el-Utbi'nin Kitab-ı Yemini adlı eserinde de rastlamaktayız. Harika bir yaradılışa, asil bir ruha, mükemmel bir karaktere sahip olduğundan diğer yöneticiler arasında farklı bir üne ulaştığını abartılı bir ifadeyle dile getirmesini Kâbus'a uzun süre kâtiplik yapmasından kaynaklandığını söyleyebiliriz. ${ }^{15}$

Gazneli Sultan Mahmud ile yakın münasebetler kurmuş ve Abbasi halifesinden başka kimseyi metbu tanımamıştır. Devlet yönetimi konusunda oldukça titiz davranan Kâbus, en küçük bir suç ve ya da herhangi bir şüpheden dolayı insanları kolaylıkla ölümle cezalandırabiliyordu. Bu durum ordusundaki komutanların kendisini tahttan indirmek için harekete geçmelerine neden olmuştur. 0 sıralarda Taberistan valiliğinde bulunan oğlu Ebû Mansûr Minûçihr'i tahta çıkarmak istemişlerdir. Tahtı başkasına kaptırmak istemeyen Minûçihr, isyan eden komutanlarla ittifak yapmıştır. Kâbus bu durum karşısında tahtı oğluna bırakmak zorunda kalmıştır. Fakat asi askerler

${ }^{14}$ Alirıza Anısı, Early Islamic Architecture In Iran, Basılmamıs Doktora Tezi, University of Edinburg, 2007, s.25.

${ }^{15}$ Kâbus b. Veşmgir hakkında daha fazla malumat için bakınız. El-Utbi, Kitab-ı Yemini, translated: James Reynolds, London, 1958, s.314.

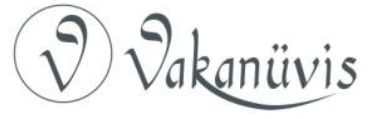


Kâbus'un hayatta kalmasının kendileri için tehdit olduğunu düşündükleri için onu öldürmüşlerdir. ${ }^{16}$

Minûçihr'in Dârâ adında başka bir kardeşi vardı. Dârâ, Kâbus hayattayken onunla anlaşmazlığa düşerek Gazneli Sultan Mahmud'a sığınmıştı. Dârâ'yı tahta getirtmek için Arslan Cazip komutasında bir orduyu Ziyârilerin üzerine sevk eden Sultan Mahmud, Minûçihr'in itaat etmesi ve beş yüz bin dinar haraç ödemesiyle tahtta kalmasına müsaade etti. Kızlarından birini Minûçihr ile evlendirdi. Fakat bu evlilik Minûçihr'e bir üstünlük sağlamamış, o da öteki vasallar gibi istendiğinde Mahmud'un seferlerine asker göndermiştir. Gazneliler Rey şehrini ele geçirdiklerinde Minûçihr Sultan Mahmud'u kendi toprakları içinde karşılamış, dört yüz bin dinar para ödediği gibi Gazne ordusunun erzak ihtiyacını da karşılamıştır. ${ }^{17}$

Gazneliler devri tarihçisi Beyhaki'nin Tarih-i Beyhaki adlı eserinde Minûçihr'in tahtını garanti altına almak için henüz Gazneli tahtına geçmemiş olan Sultan Mahmud'un oğlu Mesud ile gizli gizli mektuplaştığı ifade edilir. ${ }^{18}$ Değişmesi muhtemel durumlar karşısında her hanedan üyesi bulunduğu bölgedeki hâkimiyetini mutlak kılmak için bu tür yollara başvurduğunu görmekteyiz. Nitekim Minûçihr ölüp de yerine oğlu Enûşirvân geçince beş yüz bin dinar karşııı̆ında Gazneli Devleti'ne bağııı̆̆ını arz ederek tahtını garantiye alması da bu duruma bir örnek teşkil edebilir. ${ }^{19}$

${ }^{16}$ ibn İsfendiyar, Tarih-i Taberistan: An Abridged Translation of History of Tabaristan, s.232; ibnü'I-Esîr, el-Kâmil fi't-Tarih, C.IX, s.191; Keykâvus b. İskender, Kabusnâme, s.203; Erdoğan Merçil, Gazneliler Devleti Tarihi, TTK Basımevi, Ankara, 1989, s.41; Ahmet Güner, "Kâbus b. Veşmgir", İlam Ansiklopedisi, C.XXIV, Türkiye Diyanet Vakfı Yayınları, İstanbul, 2001, s.44; Madelung, "The Minor Dynasties of Northern Iran", s.215.

${ }^{17}$ ibn İsfendiyar, Tarih-i Taberistan: An Abridged Translation of History of Tabaristan, s.233; Utbi, Kitab-ı Yemini, s.414; Merçil, Gazneliler Devleti Tarihi, s.41; Madelung, "The Minor Dynasties of Northern Iran", s.216; Merçil, "Ziyariler", s.499.

18 Beyhakî, Beyhakî Tarihi, Çev. Necati Lügal, Yayımlanmamış Tercüme, Ankara, 1945, s.152-153.

${ }^{19}$ Merçil, Gazneliler Devleti Tarihi, s.41; Madelung, "The Minor Dynasties of Northern Iran", s.214.

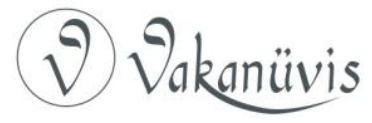


Bu sıralarda Sultan Mesud, Enûşirvân üzerinde etkili olan Ebu Kâlicâr'ı akrabalık yoluyla kendisine bağlamaya çalışmış ve kızıyla evlenmiştir. Sultan Mesud yıllık verginin ödenmesine çok dikkat ediyordu. Ancak Ebu Kâlicâr vergiyi düzenli ödemeyince Mesud Hazar denizi sahillerine bir sefer yaptı. Gazneli ordusu bu sefer esnasında Cürcân ve Taberistan'ı ele geçirdi. Ebu Kâlicâr, Enûşirvân ve diğer emirlerle beraber Gazneli ordusundan kaçmış ve sonunda Sultan Mesud'dan af dilemişlerdir. Gazneli ordusunun bu bölgeden geri çekilmesini fırsat bilen Ebu Kâlicâr, tekrar bölgede hâkimiyetini kabul ettirmiştir. Ancak Gazneliler'e karşı vergi ödemeye devam etmiştir. 1040 yılında Enûşirvân, bölgede hâkimiyeti kendi lehine çevirip, Ebu Kâlicâr'ı esir etmiş ve tekrar Ziyâri hükümdarı olmuştur. ${ }^{20}$ Beyhakî̀de bu konuyla ilgili daha farklı bilgilere rastlanmaktadır. Minûçihr'in oğlu Enûşirvan'ın, Kâlicâr ve Minûçihr'in hacib-i büzürgü tarafından zehirlenerek öldürüldüğü kaydedilmiştir. Ayrıca Enûşirvan'ın ölümüyle Veşmgir ve Minûçihr soyundan padişahlık edecek kimsenin kalmaması, dolayısıyla kendisinin tahta geçmek için Gazneli hükümdarından tasdik istemesi, Gazneli yönetimi tarafından kendisine hilatler verilmesi ve emirliğinin tasdik edilmesi bilgileri yer alır. Ebu Kâlicâr'ın bir dönem Ziyâri hanedanının başına geçtiği bilgisi doğrudur fakat Enûşirvan'ın ölümüyle ilgili bu tür bir bilgiye diğer kaynaklarda rastlamamaktayız.

Ziyârilerin Gazneli Devleti'ne tâbi olarak kalması, Selçukluların Horasan'a gelmesi ve Gaznelilerle Dandanakan Savaşı'nı gerçekleştirip onların topraklarına yerleşmeye başlayıncaya kadar sürmüştür. Ayrıca şunu da belirtmek gerekir, Minûçihr'in ölümüyle Ziyâriler eski gücünü kaybetmeye başlamıştır hatta Hazar bölgesinde ve dış işlerde hiçbir zaman önemli bir role sahip olamamıştır. ${ }^{21}$

\section{Selçukluların Taberistan'a Gelmesi ve Bölgedeki Faaliyetleri}

Selçukluların kendi bünyesindeki iç şartlar ve devletlerarası dış şartlar açısından, Selçuklu Oğuzlarının kaderinde yeni bir perde açan

20 Merçil, "Ziyâriler", s.499; Madelung, "The Minor Dynasties of Northern Iran", s.216.

${ }^{21}$ C. E. Bosworth, "On The Chronology of Ziyarids In Gurgan and Tabaristan", Der Islam: Journal of The History and Culture of the Middle East, 40/1, (1964), p. 25.

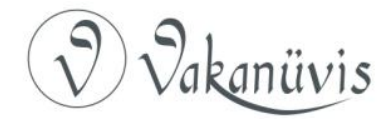


Dandanakan sonrası devir, sosyal ve iktisadi bakımdan harap Horasan kıtasından günümüze kadar gelecek olan bir tarihin temellerinin atıldığı devir olmuştur. ${ }^{22}$ Yeni kurulan devlet feodal esaslara göre taksim edilmiştir. Tuğrul Bey, Sultan sıfatı ile Nişabur'a ve batıda fethedilecek yerlere, Çağrı Bey, Melik sıfatı ile ve ordu kumandanı olarak yine hükümet merkezi Merv olmak üzere, Ceyhun'a, Serahs ve Belh şehirleri ile Gazne'ye kadar uzanan ülkelere sahip olmuştur. İnanç Bey, eski Türkçe unvanını (Yabgu) koruyarak Herat merkez olmak üzere Bust, İsfizar ve Sistan'a kadar alınacak bölgelerin hükümdarı olmuştur. ${ }^{23}$

Selçuklular Dandanakan Savaşı'nı müteakip on beş yıl içinde hızı bir büyüme göstermiştir. Tuğrul Bey, Taberistan ve Cürcân'a yönelmiştir. Daimi bir surette karışıklı içinde olan Taberistan bölgesi, Selçuklu kuvvetleri tarafından ele geçirilmiştir. ${ }^{24}$ íbn İsfendiyar Selçukluların bölgeye gelmesini şöyle ifade eder: "Sultan Mesud Cürcân'a çekildiği sıralarda, iki bin Türkmen, Selçuk'un oğulları ve Türkmen beylerinden Yağmur ve Buka'nın Merv'e doğru hareket ettiği haberini aldı. Bu Selçukluların ilk isyanı niteliğindeydi ve güçleri Çağrı Bey'in Harezm'i zapt etmesine kadar artarak devam etti. Taberistan ve Cürcân'a doğru ilerlediler. Ziyârilerin bütün hâkimiyet alanlarını ele geçirdiler." ${ }^{25}$ Tarih-i Taberistan'da gayet yüzeysel verilen bu bilgiler İbnü'l Esir'in el-Kâmil fi't-Tarih'inde daha tafsilatlıdır. 1042 yıında Tuğrul Bey'in Cürcân ve Taberistan'ı zapt etmesinin sebebini şöyle açıklamaktadır: "Taberistan ve Cürcân hâkimi olan Enûşirvan b. Minûçihr, ordu kumandanı ve üvey babası olan Ebu Kâlicâr b. Veyhân'ı annesinin de yardımıyla alıkoydu. Bunun üzerinde bu ülkeyi ele geçirmesine hiçbir mani kalmadığını düşünen Tuğrul Bey, derhal Cürcân ve Taberistan üzerine yürüdü. Önce Merdâviç b. Bessû ile birlikte Cürcân'a hareket etti. Tuğrul Bey Cürcân önüne karargâh kurunca şehirde oturanlar ona kapılarını açtılar. Tuğrul

${ }^{22}$ Ergin Ayan, “Büyük Selçuklu Devleti’nin Temelleri Atılırken Siyasi Meşruiyet Süreci", Ordu Üniversitesi Sosyal Bilimler Araştırmaları Dergisi, 3/5 (2012), s.19.

${ }^{23}$ Osman Turan, Selçuklular Tarihi ve Türk-Islam Medeniyeti, Turan Neşriyat, İstanbul, 1969, s.67.

${ }^{24}$ Osman Gazi Özgüdenli, Selçuklular, Büyük Selçuklu Devleti Tarihi, C.I, iSAM Yayınları, İstanbul, 2013, s.92.

25 Ibn İsfendiyar, Tarih-i Taberistan: An Abridged Translation of History of Tabaristan, s.235.

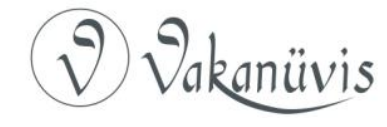


Bey şehre girip, halkın barış yoluyla yüz bin dinar vergi ödemesini kararlaştırdı ve burayı Merdâviç'e teslim etti. Merdâviç, Cürcân'a bağı yerlerin tamamı için her yıl elli bin dinar vergi ödeyecekti. Tuğrul Bey bu işleri hallettikten sonra Nişabur'a döndü. ${ }^{\prime 26}$ Enûşirvan üzerinde etkili bir kişilik olan Ebu Kâlicâr İbnü'l-Esir tarafından Enûşirvan'ın üvey babası olarak kaydedilmiştir. Beyhakî ise dayısı olduğunu belirtmiştir. ${ }^{27}$ Fakat Ebu Kâlicâr hakkında Enûşirvan'ın anne tarafından akrabası ve Ziyâri ordusunda görevli bir komutan olması dışında başka bir malumata sahip değiliz.

El-Bundari'nin Zubdetu'l-Nusra ve Nuhbetu'I-Usra adlı eserinde Tuğrul Bey'in Deylem illerinde o kadar çok define ve hazine bulduğundan bahseder ki onlar sayesinde darlık günlerinin uğurlu günlere dönüştüğünü aktarır. ${ }^{28}$ Yazarın Deylem illerinden kastı Taberistan bölgesidir. Bize aktarılan bu bilgiler ışığında bölgenin Selçuklulara ekonomik açıdan gelir sağladığı sonucuna varabiliriz.

Tuğrul Bey'in Selçuklu Devleti'nin başına geçip seferler düzenlediği yıllarda İran coğrafyasında muhtelif yerlerde hâkimiyet süren mahalli hanedanlardan ilk olarak Ziyârileri kontrol altına almış ve vergiye bağlamıştır. Ayrıca Ziyâriler Selçuklulara hiçbir surette mukavemet göstermemiştir. ${ }^{29}$ Tâbi devletlerle metbû hükümdar ilişkileri meselesinde üzerinde durulacak başka bir mesele ise tâbi hükümdarların ölümlerinden sonra ortaya çıkan durumdur. Ölen tâbi hükümdarın yerine meşru varislerinden birinin tahta geçmesi ancak metbû hükümdarın rızasıyla mümkündü. ${ }^{30}$ Nitekim yukarda belirttiğimiz gibi Tuğrul Bey Taberistan'a geldiği zaman Enûşirvan'ın yerine Merdâviç b. Bessû'yu bölgenin idaresine tayin etmesi buna bir örnektir. Enûşirvan, Merdâviç̧in kontrolü altında Taberistan bölgesinde yaşamını sürdürmüştür. Enûşirvan'ın ölüm tarihi hakkında

\footnotetext{
${ }^{26}$ ibnü'l-Esir, el-Kâmil fi't-Tarih, C.IX, s.378-379.

${ }^{27}$ Beyhakî, Beyhakî Tarihi, s.410.

28 El-Bundari, Zubdetu'l-Nusra ve Nuhbetu'l-Usra, Çeviren: Kıvameddin Burslan, Türk Tarih Kurumu Basımevi, Ankara, 1999, s.6.

${ }^{29}$ Mehmet Altay Köymen, Selçuklu Devri Türk Tarihi, Türk Tarih Kurumu Basımevi, 1999, s.143.

${ }^{30}$ Mehmet Altay Köymen, Tuğrul Bey ve Zamanı, MEB Yayınları, İstanbul 1976, s.30.
}

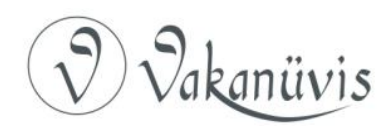


bilgiler belirsizdir. Muhtemelen 1049-1050'ye kadar Ziyâri hanedanını yönetmiştir. Ondan sonra kuzeni İskender b. Keykavus Taberistan'ın dağlık bölgelerinde1069-1070'lere kadar hüküm sürmüştür. İskender'den sonra Gilanşah başka güçlerin gölgesinde hayatını idame ettirmiştir. $^{31}$

Sultan Alparslan döneminde de bölge hâkimiyetini güçlendirmek için İnanç Yabgu görevlendirilmiştir. Selçukluların dönem dönem bölge hâkimiyetini ellerinde tutmak için gerek Selçuklu hanedan üyelerinden gerekse hanedan dışından valileri tayin etmiştir. Ziyâriler hanedanı 11. yüzyılın son çeyreğine kadar Selçuklulara bağlı bir hanedan olarak yaşamıştır. $^{32}$

\section{Sonuç}

Tarih boyunca Taberistan birçok hanedana ev sahipliği yapmış bir bölge olma özelliği gösterir. Bu bölgenin tarihini belirli bir zaman diliminde incelediğimizde bir takım karmaşık olay örgüsüne rastlamaktayız. Bunda gerek tarihi kaynakların bizlere verdiği bilgilerin yetersizliği gerekse günümüze ulaşamamış kaynakların yokluğu önemli bir faktördür. Bölgede hüküm sürmüş hanedanlardan Ziyâriler, İran coğrafyasının ön plana çıkmış mahalli hanedanlarından biridir. Siyasi tarihini incelediğimizde Ortaçağ İranı'nda önemli bir yere sahip olduğunu görmekteyiz. Nitekim bu hanedanın bir buçuk asırdan fazla bir süre Taberistan bölgesinde hüküm sürmesi ve yaptığı faaliyetler buna örnek gösterilebilir. Soylarını Sâsânilere dayandırma çabasında olan bu hanedan, hüküm sürdüğü 10. ve 11.yüzyıllarda siyasi anlamda bir karmaşanın yaşandığı bu dönemlerde eski İran kültürüne sarılmaya çalışmaları kendilerine pozitif bir katkıda bulunacağı kanaatindeydiler. Bunun izlerine Ziyârilerin son dönem hanedan üyelerinden Keykavus b. İskender'in nasihatname türünde yazdığı Kabusnâme adlı eserinde de rastlamaktayız.

31 ibn İsfendiyar, Tarih-i Taberistan: An Abridged Translation of History of Tabaristan, s.236; Bosworth, "On The Chronology of Ziyarids In Gurgan and Tabaristan", s.31; C. E. Bosworth, "Ziyarids", Encyclopedia of Islam, Vol. XI, Brill, Leiden, 2002, 540.

32 Özgüdenli, "Taberistan”, s.322; Merçil, "Ziyâriler", s.499.

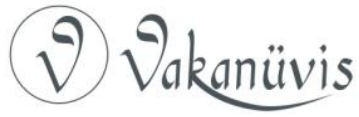


Taberistan kendine özgü coğrafyası ile bölgeye varılabilmesi, sınırlı sayıdaki ulaşım hatlarına bağlı olduğundan, diğer bölgelere göre istila ve saldırılara karşı savunan tarafa verdiği avantajlar ile doğal bir kale işlevi görmüştür. Bu yüzden tarih boyunca topraklarında hüküm süren yöneticiler için güvenli bir bölge olmuştur. Bölgede hüküm süren hanedanların zaman zaman bağımsız, dönemin değişen şartlarına göre de yarı bağımsız hareket ettiklerini görmekteyiz. Nitekim Ziyârilerin Sâmânîler, Büveyhîler, Gazneliler ve son olarak da Selçukluların hâkimiyeti altında yaşaması siyasi, askeri ve ekonomik anlamda onları tam bağımsız kılamamıştır. Metbû tanıdığı hükümdarlara belirli bir miktar haraç ödemek, seferlere asker göndermek, hutbelerde öncelikle metbû hükümdarın adını okutmak, metbû hükümdarın uygun gördüğü yöneticiyi tâbi hanedanın başına getirmesi gibi hâkimiyet alametleri Ziyârilerin tam bağımsız hareket edemediğine birer kanıttır. Duruma akrabalık ilişkileri açısından bakacak olursak Ziyârilerin zaman zaman hanedan ilişkileri kurarak dahil oldukları devletlerin siyasi politikalarına da etki etmek istemeleri kuvvetle muhtemel olarak değerlendirilebilir.

Selçuklular cihetinden Ziyâri ilişkileri kaynakların verdiği bilgilerin kısıtlı olması nedeniyle çok tafsilatlı değildir. Bu iki hanedanın münasebetlerini içeren bilgiler her ne kadar yüzeysel olsa da anladığımız ve yorumlayabildiğimiz kadarıyla karmaşık ve mücadelelerde dolu değildir. Selçukluların etkin olmaya başladığı dönemlerde Taberistan'a gelerek hiçbir güçle karşılaşmadan Ziyâriler ile iyi ilişkiler kurması metbûluk-tâbilik kavramının doğal bir sonucudur. Selçukluların Horasan'a gelerek Gazneli Devleti gibi büyük bir siyasi gücü tahtından alıkoyup kısa süre içinde İran coğrafyasına hükmetmeleri onları dönemin mutlak gücü haline getirdiği için yöneldikleri bölgelerde kolaylıkla hâkimiyet sağlamışlardır. Ayrıca bu mutlak gücün temelini Oğuzların oluşturduğu değişmez bir gerçektir.

Siyasi olayları ön planda tutarken onları ayrıca dini açıdan da değerlendirmek gerekir. Halifelik makamının önemini burada bir kez daha vurgulamak yerinde olacaktır. Ziyâri yöneticilerinin bazıları dönemin halifesinden bir takım unvanlar almıştır. Halifeden unvan almak o dönemler için gayet itibar kazandıran bir durumdu ve pek çok İslam devletinin geleceğini ilgilendiren meseleler halifelik makamından

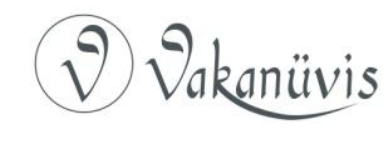


aldıkları meşruiyetle şekillenmekteydi. Bu meşruiyeti kazanmak da ancak askeri zaferlerle mümkündü.

Ziyârileri kültürel açıdan değerlendirdiğimizde bölgenin tarihinde önemli izler bıraktığını görürüz. Birçok şair, kâtip, hekim Ziyâri sarayında yetişmiştir. İbn-i Biruni, İbn Sinâ gibi tanınmış kişiler bunlardan sadece birkaçıdır. Mimari olarak onlardan günümüze kalmış bir anıt bulunmaktadır. Kâbus b. Veşmgir tarafından inşa ettirilen bu anıta Kâbus anıtı denilmektedir ve İran Türkmenlerinin yaşadığı Günbed-i Kavus kentinde yer almaktadır.

\section{Kaynakça}

Akçay, Filiz, Zeynül'-Ahbâr (Tâhiriler, Saffâriler, Sâmânîler ve Gazneliler ile ilgili Kısımlar), Basılmamış Yüksek Lisans Tezi, Ordu Üniversitesi, Sosyal Bilimler Enstitüsü, Ordu, 2015.

Anısı, Alirıza, Early Islamic Architecture In Iran, Basılmamış Doktora Tezi, University of Edinburg, 2007.

Ayan, Ergin, “Büyük Selçuklu Devleti'nin Temelleri Atılırken Siyasi Meşruiyet Süreci", Ordu Üniversitesi Sosyal Bilimler Araştırmaları Dergisi, 3/5 (2012), s.17-37.

Beyhakî, Beyhakî Tarihi, Çev. Necati Lügal, Yayımlanmamış Tercüme, Ankara, 1945.

Bosworth, C. E., "On The Chronology of Ziyârids In Gurgan and Tabaristan", Der Islam: Journal of The History and Culture of the Middle East, 40/1, (1964), s.25-34.

Bosworth, C. E., "Ziyârids", Encyclopedia of Islam, Vol. XI, Brill, Leiden, (2002), s.539-540.

El-Bundari, Zubdetu'I-Nusra ve Nuhbetu'I-Usra, Çeviren: Kıvameddin Burslan, Türk Tarih Kurumu Basımevi, Ankara, 1999.

El-Utbi, Kitab-I Yemini, translated: James Reynolds, London, 1958.

Güner, Ahmet "Merdâviç b. Ziyâr", İslam Ansiklopedisi, C.XXIX, Türkiye Diyanet Vakfı Yayınları, İstanbul, (2004), s.178-179.

Güner, Ahmet, "Kâbus b. Veşmgir", İlam Ansiklopedisi, C.XXIV, Türkiye Diyanet Vakfı Yayınları, İstanbul, (2001), s.43-44.

Ibn Havkal, Mesalik ve'l Memalik, The Oriental Geography, translated: William Ouseley, Oriental Press, London, 1800.

Ibn İsfendiyar, Tarih-i Taberistan: An Abridged Translation of History of Tabaristan, translated: Edward Browne, Volume: II, Printed by: E.J. Brill, Leiden, 1905.

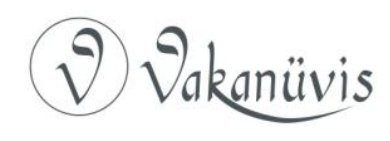


İbnü'l Fakîh, Ebubekir Ahmed b. Muhammed el-Hemedanî, Muhtasar Kitâbü'I-Büldan, Edit: M.J.De Geoje, Leiden, 1885.

İbnü'l-Esir, el-Kâmil fi't-Tarih, Çev: Abdülkerim Özaydın, C.VIII, Bahar Yayınları, ìstanbul, 1989.

İstahrî, Ebu İshak Muhammed b. el-Farisi, Kitabü'l Mesâlik ve'l-Memâlik, Leiden, 1992.

Keykâvus b. İskender, Kabusnâme, Farsça'dan Çev. ilyasoğlu Mercimek Ahmed, Hazırlayan ve Sadeleştiren: Atilla Özkırımlı, C.ı, Kervan Yayınları, İstanbul.

Köymen, Mehmet Altay, Selçuklu Devri Türk Tarihi, Türk Tarih Kurumu Basımevi, 1999.

Köymen, Mehmet Altay, Tuğrul Bey ve Zamanı, MEB Yayınları, İstanbul 1976.

Madelung, V., "The Minor Dynasties of Northern Iran", The Cambridge History of Iran, Edit by R.N. Frye, Vol. IV, Cambridge University Press, Cambridge, (2008), s.198-249.

Merçil, Erdoğan, "Ziyâriler", İslam Ansiklopedisi, C.XLIV, Türkiye Diyanet Vakfı Yayınları, i̇stanbul, (2013), s.498-499.

Merçil, Erdoğan, Gazneliler Devleti Tarihi, TTK Basımevi, Ankara, 1989.

Minorsky, Vladimir, Hudud al-Alam, The Region of the World, Edit: C.E. Bosworth, London, 1970.

Özgüdenli, Osman Gazi, “Taberistan”, İlam Ansiklopedisi, C.XXXIX, Türkiye Diyanet Vakfı Yayınları, İstanbul, (2010), s.322-323.

Özgüdenli, Osman Gazi, Selçuklular, Büyük Selçuklu Devleti Tarihi, C.I, iSAM Yayınları, İstanbul, 2013.

Strange, Guy Le, The Lands of The Eastern Caliphate, Mesopotamia, Persia and Central Asia From The Moslem Conquest to The time of Timur, Cambridge University Press, Cambridge, 1905.

Turan, Osman, Selçuklular Tarihi ve Türk-Islam Medeniyeti, Turan Neşriyat, İstanbul, 1969.

Yaşaroğlu, Hasan, Taberistan Zeydileri, Basılmamış Doktora Tezi, Marmara Üniversitesi, Sosyal Bilimler Enstitüsü, İstanbul, 1998. 